Abstracta Iranica Abstracta Iranica

Revue bibliographique pour le domaine irano-aryen

Volume 23 | 2002

Comptes rendus des publications de $\mathbf{2 0 0 0}$

\title{
Qajar Iran, and the Rise of Reza Khan 1796-1925. Costa Mesa, Mazda, 1999, 134 p.
}

\section{Bernard Hourcade}

\section{Q OpenEdition}

1 Journals

Édition électronique

URL : http://journals.openedition.org/abstractairanica/35403

DOI : 10.4000/abstractairanica.35403

ISSN : 1961-960X

\section{Éditeur :}

CNRS (UMR 7528 Mondes iraniens et indiens), Éditions de l'IFRI

\section{Édition imprimée}

Date de publication : 15 mai 2002

ISSN : 0240-8910

\section{Référence électronique}

Bernard Hourcade, «Qajar Iran, and the Rise of Reza Khan 1796-1925. Costa Mesa, Mazda, 1999,

134 p. », Abstracta Iranica [En ligne], Volume 23 | 2002, document 150, mis en ligne le 08 février 2010, consulté le 25 septembre 2020. URL : http://journals.openedition.org/abstractairanica/35403 ; DOI : https://doi.org/10.4000/abstractairanica.35403

Ce document a été généré automatiquement le 25 septembre 2020.

Tous droits réservés 


\title{
Qajar Iran, and the Rise of Reza Khan 1796-1925. Costa Mesa, Mazda, 1999,
} $134 \mathrm{p}$.

\author{
Bernard Hourcade
}

Cet ouvrage de synthèse retrace de façon claire les lignes de force d'un siècle et demi d'histoire, mais il offre surtout une relecture de l'histoire Qajar, en montrant que cette période n'a pas été, comme on le dit trop souvent, un lent déclin, un long marasme dans un monde alors bouleversé par l'industrialisation et les idées nouvelles. N.R.K. montre que l'Iran Qajar a vécu profondément tous les grands débats importants, que les bases de ce qui s'est ensuite passé au $20^{\mathrm{e}} \mathrm{s}$. étaient bel et bien préparées, ce qui explique leur émergence qui n'a été brutale qu'en apparence. Par rapport à l'Égypte ou à la Turquie Ottomane, la Perse n'a pas pu mettre en œuvre ces évolutions car elle était physiquement en dehors des grands courants d'échange avec l'Europe, bloquée par la rivalité anglo-russe, dominée par les tribus nomades. Ce livre est donc une réécriture stimulante d'une histoire que l'on a trop vite stéréotypée. L'ouvrage se termine par un article de F. Ghaffary sur les lieux de spectacles en Perse (version mise à jour d'un article paru en 1992 en français).

\section{INDEX}

Thèmes : 4.2.1. Safavides et Qâjârs 
AUTEURS

BERNARD HOURCADE

CNRS - Paris 